Sonny Lontoh • Alan A. DiSpirito

Jeremy D. Semrau

\title{
Dichloromethane and trichloroethylene inhibition of methane oxidation by the membrane-associated methane monooxygenase of Methylosinus trichosporium 0B3b
}

Received: 3 November 1998 / Accepted: 1 March 1999

\begin{abstract}
Whole-cell assays were used to measure the effect of dichloromethane and trichloroethylene on methane oxidation by Methylosinus trichosporium OB3b synthesizing the membrane-associated or particulate methane monooxygenase (pMMO). For M. trichosporium OB3b grown with $20 \mu \mathrm{M}$ copper, no inhibition of methane oxidation was observed in the presence of either dichloromethane or trichloroethylene. If $20 \mathrm{mM}$ formate was added to the reaction vials, however, methane oxidation rates increased and inhibition of methane oxidation was observed in the presence of dichloromethane and trichloroethylene. In the presence of formate, dichloromethane acted as a competitive inhibitor, while trichloroethylene acted as a noncompetitive inhibitor. The finding of noncompetitive inhibition by trichloroethylene was further examined by measuring the inhibition constants $K_{\mathrm{iE}}$ and $K_{\mathrm{iES}}$. These constants suggest that trichloroethylene competes with methane at some sites, although it can bind to others if methane is already bound. Whole-cell oxygen uptake experiments for active and acetylene-treated cells also showed that provision of formate could stimulate both methane and trichloroethylene oxidation and that trichloroethylene did not affect formate dehydrogenase activity. The finding that different chlorinated hydrocarbons caused different inhibition patterns can be explained by either multiple substrate binding sites existing in pMMO or multiple forms of pMMO with different activities. The whole-cell analysis performed here cannot distinguish between these models, and further work should be done on obtaining active preparations of the purified $\mathrm{pMMO}$.
\end{abstract}

\footnotetext{
S. Lontoh · J. D. Semrau (西)

Department of Civil and Environmental Engineering,

The University of Michigan, 1351 Beal Avenue,

Ann Arbor, MI 48109-2125, USA

e-mail: jsemrau@engin.umich.edu

Tel. +1-734-7646487; Fax +1-734-7632275

A. A. DiSpirito

Department of Microbiology, Iowa State University, Ames, IA 50011-3211, USA
}

Key words Particulate methane monooxygenase . Trichloroethylene $\cdot$ Dichloromethane $\cdot$ Inhibition

Abbreviations $M M O$ Methane monooxygenase . pMMO Particulate methane monooxygenase $\cdot s M M O$ Soluble methane monooxygenase $\cdot A M O$ Ammonia monooxygenase

\section{Introduction}

Chlorinated hydrocarbons are some of the most widely reported groundwater pollutants in the United States (Westrick et al. 1984). Due to their toxicity and prevalence in the environment, a great deal of research has examined a variety of systems to remove such compounds from contaminated soils and aquifers. Some methods, e.g., air-stripping and vacuum extraction, rely on the volatility of these compounds to remove them from the subsurface. Other mechanisms involve the use of microorganisms to transform these compounds to less hazardous products. For many contaminants, biodegradation is a cometabolic event, i.e., degradation can only be sustained in the obligate presence of an alternative substrate that serves as a carbon and energy source (McCarty 1997). Often this growth substrate is transformed by the same enzyme that degrades the chlorinated hydrocarbon. Thus, the simultaneous presence of a growth substrate and a pollutant results in inhibition of the transformation of both compounds. Such competition can cause significant reduction in pollutant degradation and/or cell survival and growth, thus limiting the effectiveness of biodegradation.

Methanotrophs, a group of gram-negative bacteria that utilize methane as their sole source of carbon and energy, are a prime example of this problem. These cells are ubiquitous in nature and have been shown to degrade many different chlorinated hydrocarbons (Hanson and Hanson 1996; Oldenhuis et al. 1989). The enzyme responsible for the initial oxidation of methane, methane monooxygenase (MMO), can also oxidize chlorinated aliphatic and aromatic hydrocarbons. To effectively utilize methanotrophs 
for clean-up of polluted sites, it is necessary to know what type of inhibition exists between methane and various chlorinated hydrocarbons.

Methanotrophic degradation of chlorinated hydrocarbons is further complicated by the fact that multiple forms of MMO have been found. The best-characterized form is found in the cytoplasm and is termed soluble methane monooxygenase (sMMO). The genes for sMMO have been cloned and sequenced (Cardy et al. 1991), the crystal structure of the hydroxylase component has been determined (Rosenzweig et al. 1993), and simultaneous substrate degradation in both purified sMMO and whole-cell studies has been shown to follow competitive inhibition kinetics (Fox et al. 1990; Speitel et al. 1993). Not all methanotrophs, however, can synthesize sMMO. Rather, most known methanotrophs can synthesize only a membranebound or particulate methane monooxygenase (pMMO). This form of MMO is found in all known methanotrophs, but relatively little is known about its structure. The genes for pMMO have been cloned and sequenced (Semrau et al. 1995a), and there has been some success on purification, but with limited activity (Zahn and DiSpirito 1996; Nguyen et al. 1998; Takeguchi et al. 1998). For those strains that can synthesize both SMMO and pMMO, the copper/biomass ratio is important in regulating the relative amounts and activity of sMMO and pMMO. sMMO is synthesized only at low copper/biomass ratios (less than $0.89 \mu \mathrm{mol}$ copper/g cell dry wt.) (Hanson and Hanson 1996). Above this ratio, pMMO is expressed, and recent work shows that increasing the copper/biomass ratio above this value also changes the activity and substrate range of cells expressing pMMO. (Zahn and DiSpirito 1996; Smith et al. 1997; Lontoh and Semrau 1998).

Little information exists on the kinetics of multiple substrate degradation by methanotrophs synthesizing pMMO. Previous studies have shown that one methanotroph, Methylosinus trichosporium OB3b, can degrade both dichloromethane and trichloroethylene when expressing pMMO (DiSpirito et al. 1992; Van Hylckama Vlieg et al. 1996; Lontoh and Semrau 1998). Here we extend those experiments to consider the inhibition of methane oxidation by dichloromethane and trichloroethylene in whole cells of M. trichosporium OB3b expressing pMMO. These experiments were performed since:

1. Most bioremediation schemes will utilize whole-cell systems.

2. It is reasonable to expect that pMMO will be synthesized by many in situ methanotrophic communities since most known methanotrophs only express pMMO.

3. In situ cell density can be low, which leads to high copper/biomass ratios favoring expression of pMMO by those cells that can synthesize both forms of MMO.

sMMO and pMMO have different substrate specificities (Burrows 1984) and little to no DNA or protein sequence similarity (Semrau et al. 1995a); therefore, they may bind substrates differently and have different patterns of inhibition in the presence of the same inhibitor. Thus, it is nec- essary to know the effect of halogenated hydrocarbons on the oxidation of the growth substrate, methane, by cells synthesizing pMMO. Specifically, the results presented here will help determine natural attenuation rates by methanotrophs and will also assist in the optimization of bioremediation schemes by in situ methanotrophic populations. Data presented here show that the patterns of inhibition by dichloromethane and trichloroethylene on methane oxidation by whole cells are different. Dichloromethane acted as a competitive inhibitor, but methane oxidation in the presence of trichloroethylene was best explained using a noncompetitive inhibition model. The different types of inhibition are possible if multiple binding sites exist within pMMO or if multiple forms of pMMO are being expressed. These possibilities and comparisons to similar studies done on ammonia monooxygenase (AMO), another copper-containing monooxygenase very similar to $\mathrm{pMMO}$, are discussed in this report.

\section{Materials and methods}

Culture conditions and experimental procedures

M. trichosporium OB3b (ATCC 35070) was grown in nitrate mineral salts (NMS) medium with $20 \mu \mathrm{M}$ copper as $\mathrm{Cu}\left(\mathrm{NO}_{3}\right)_{2} \cdot 2.5\left(\mathrm{H}_{2} \mathrm{O}\right)$ at $30^{\circ} \mathrm{C}$ as described previously (Lontoh and Semrau 1998). Biomass concentrations were measured as protein using the Biorad Protein Assay Kit with bovine serum albumin as a standard. To monitor for expression of sMMO, the naphthalene assay specific for sMMO activity was used for all cell suspensions (Brusseau et al. 1990).

Assays of methane consumption in the presence of dichloromethane and trichloroethylene

After the cells had been harvested, residual methane was removed from the growth flasks by evacuating the flask five times and allowing air to re-equilibrate after each evacuation. Aliquots $(3 \mathrm{ml})$ were then aseptically transferred to $20-\mathrm{ml}$ serum vials. The protein concentrations of these cell suspensions varied between 0.091 and $0.099 \mathrm{mg}$ protein $\mathrm{ml}^{-1}$. These vials were capped with teflon- coated rubber butyl stoppers (Wheaton) and were sealed with aluminum crimp seals. For each concentration of methane and trichloroethylene examined in these assays, duplicate samples were created with one control. The control was made by adding $50 \mu \mathrm{l} 5 \mathrm{~N} \mathrm{NaOH}$ to lyse the cells and was used to assess abiotic disappearance of the substrate, which was less than $2.2 \%$ in $10 \mathrm{~h}$ for both methane and trichloroethylene.

Initial methane, dichloromethane, and trichloroethylene concentrations varied from 1 to 81,0 to 24 , and 0 to $61 \mu \mathrm{M}$, respectively. Formate $(20 \mathrm{mM})$, as sodium formate, was added in some experiments as it had been shown to enhance trichloroethylene degradation by methanotrophs (Alvarez-Cohen and McCarty 1991; Lontoh and Semrau 1998). To obtain a range of aqueous methane concentrations from 1 to $81 \mu \mathrm{M}$ in solution, methane was added to the vials using Dynatech A-2 gas-tight syringes. Aqueous concentrations were calculated using a dimensionless Henry's constant of 27.02 (Morel and Hering 1991). Dichloromethane and trichloroethylene were added using Hamilton 1700 Series gas-tight syringes from a bottle of dichloromethane- or trichloroethylene-saturated water solutions as described by others (Alvarez-Cohen and McCarty 1991). For the partitioning of trichloroethylene and dichloromethane between the liquid space and the head space, dimensionless Henry's constants of 0.42 and 0.13 were used (Howard and Meylan 1997). 
Limitation of pMMO-dependent transformations by lack of dissolved oxygen was avoided by insuring that the aliquots were initially saturated with oxygen (dissolved oxygen concentration $=$ $234 \mu \mathrm{M})$ and by having a head-space/liquid-space ratio of 5.67 in the sample vials. The serum vials were also shaken at $270 \mathrm{rpm}$ at $30{ }^{\circ} \mathrm{C}$ to enhance mass transfer of methane and oxygen from the head space to the solution. Furthermore, the cell concentrations used in these experiments (approximately $0.1 \mathrm{mg}$ protein $\mathrm{ml}^{-1}$ ) were low enough to insure that the rates of biological substrate uptake, in particular for methane, were less than the rate of mass transfer from the gas phase to the liquid phase. By ensuring that mass transfer limitations were not a factor, the use of Henry's Law is justified for data analysis.

The initial rates of methane, dichloromethane, and trichloroethylene degradation were determined by taking head-space samples of $100 \mu \mathrm{l}$ at several time points, again using a Dynatech A-2 gas-tight syringe. The head-space samples were then injected into an HP 6890 GC analyzer with FID and a DB-5 capillary column (J \& W Scientific). For analysis of trichloroethylene inhibition of methane oxidation, the injector, oven, and detector temperatures were held constant at 250,120 , and $250^{\circ} \mathrm{C}$, respectively, with 36.8 $\mathrm{ml}$ helium $\mathrm{min}^{-1}$. The oven temperature was changed to $90{ }^{\circ} \mathrm{C}$ for dichloromethane inhibition assays, with a helium flow rate of $32.2 \mathrm{ml} \mathrm{min}{ }^{-1}$. These conditions provided sufficient separation of methane (retention time of either 2.0 or $2.1 \mathrm{~min}$, depending on the flow rate), dichloromethane (retention time of $2.4 \mathrm{~min}$ ), and trichloroethylene (retention time of $2.8 \mathrm{~min}$ ).

\section{Analysis of inhibition kinetics}

Methane degradation rates were determined by monitoring the decrease in the amount of methane over time based on head-space analysis. As found previously, a 2-h time frame from $t=0 \mathrm{~h}$ to $t=$ $2 \mathrm{~h}$ was appropriate for determining the initial rates of methane consumption in the presence of trichloroethylene (Lontoh and Semrau 1998). For dichloromethane, a 30-min frame from $t=0 \mathrm{~h}$ to $t=30 \mathrm{~min}$ was more appropriate since product toxicity was noted over longer time periods. These rates were then normalized to the initial cell concentration. The average of duplicate samples is reported here along with the range. The kinetic parameters of the maximal degradation rate, $V_{\max }\left[\mathrm{nmol} \min ^{-1}(\mathrm{mg} \text { protein })^{-1}\right]$, and the substrate concentration at the half-maximal degradation rate in whole cells, $K_{\mathrm{s}}(\mu \mathrm{M})$, were determined by applying nonlinear regression on the Michaelis-Menten formula using Systat V (version 5.21 for Macintosh) to the measured rates of methane consumption. The inhibition constants, $K_{\mathrm{iE}}$ and $K_{\mathrm{iES}}$, equilibrium dissociation constants for enzyme-inhibitor and enzyme-substrate-inhibitor complexes, respectively, were calculated by plotting the concentrations of trichloroethylene versus the slopes and intercepts of $V^{-1}$ vs. $S^{-1}$ plots, respectively (Cornish-Bowden 1979). Although these wholecell studies cannot give the true values of these enzymatic constants, they can give approximations (Keener and Arp 1993).

Acetylene inactivation of methane and trichloroethylene degradation

Acetylene is a selective and irreversible inhibitor of methane monooxygenase (Stirling and Dalton 1977; Prior and Dalton 1985). Cells were grown with $20 \mu \mathrm{M}$ copper and were harvested as described above. Three milliliters of cells at a concentration of $0.085 \mathrm{mg}$ protein $\mathrm{ml}^{-1}$ were then transferred to sterile 20 -ml vials. To determine the minimum inhibitory concentration of acetylene, $0-500 \mu \mathrm{l}$ acetylene was added using gas-tight syringes that provided aqueous concentrations of $0-1,037 \mu \mathrm{M}$ using a dimensionless Henry's constant of 0.87 for acetylene (Howard and Meylan 1997). M. trichosporium OB3b was then incubated for $30 \mathrm{~min}$ in the presence of acetylene. Any remaining acetylene was removed via flushing as described above for methane. Methane $(50 \mu \mathrm{M})$ was then provided in solution, and the methane consumption was monitored using GC-FID analysis. Similar experiments were performed in the presence of $50 \mu \mathrm{M}$ dichloromethane and trichloroethylene for $2 \mathrm{~h}$ after $\mathrm{pMMO}$ was inactivated with acetylene.

Oxygen uptake experiments in the presence of methane, trichloroethylene, and formate

To measure oxygen consumption by both active and acetylenetreated cells, a 1.9-ml oxygen uptake reactor was used at a constant temperature of $30^{\circ} \mathrm{C}$. An electrolyte- and membrane-covered Clarketype electrode (Instech Laboratories) was inserted into the reactor using a ground class port with two rubber O-rings and was connected to a biological oxygen monitor (Yellow Springs). Monitor output was sent to an A/D converter board (DAS08-PGL; Computer Boards) for data collection. Cells were grown and harvested as described earlier and were added to the uptake reactor at a concentration of $0.012 \mathrm{mg}$ protein $\mathrm{ml}^{-1}$ after removing residual methane. A portion of the cells was treated with acetylene to inhibit pMMO prior to adding to the uptake reactor. The cells were constantly stirred in the uptake reactor using a magnetic stirrer, and endogenous uptake of oxygen was monitored in the absence of any added substrates. Oxygen uptake was then measured in the presence of methane, trichloroethylene, and formate for both active and acetylene-treated cells.

\section{Materials}

All chemicals used in media preparation were of reagent grade or better. Highest purity methane (> 99.99\%) was obtained from Matheson Gas. Spectrophotometric grade trichloroethylene and dichloromethane (> 99.9\%) were obtained from Fisher Scientific for the degradation experiments. Distilled and deionized water from a Corning Millipore D2 system was used for all experiments. All glassware was washed with detergent and then acid-washed in $2 \mathrm{~N}$ $\mathrm{HNO}_{3}$ overnight to remove trace metals, including copper. The acid was subsequently removed by repeated rinses with distilled and deionized water.

\section{Results}

Methane consumption by M. trichosporium OB3b in the presence of trichloroethylene and dichloromethane

M. trichosporium OB3b was grown using the same conditions that had been shown earlier to preclude activity of sMMO (Lontoh and Semrau 1998). In all the experiments reported here, assuming that cell protein is $50 \%$ of the dry cell mass, the copper/biomass ratio was at a minimum of $101 \mu \mathrm{mol}$ copper per gram dry weight of cells. This is well above the maximum value of $0.89 \mu \mathrm{mol}$ copper per gram dry weight of cells, above which no sMMO activity is observed (Hanson and Hanson 1996). The naphthalene assay specific for sMMO was also used to monitor sMMO activity (Brusseau et al. 1990). In all experiments, the assay did not detect any naphthol production, showing that pMMO was the only MMO expressed by these cells under the culture conditions provided.

Figure 1 and Table 1 report the effect of dichloromethane on methane oxidation by $M$. trichosporium $\mathrm{OB} 3 \mathrm{~b}$ in the absence and presence of formate. If no formate was provided to the assay mixture, $24 \mu \mathrm{M}$ dichloromethane had no significant effect on methane oxidation. If $20 \mathrm{mM}$ formate was added, dichloromethane had a clear effect on whole-cell methane oxidation. The apparent $V_{\max }$ of meth- 
A

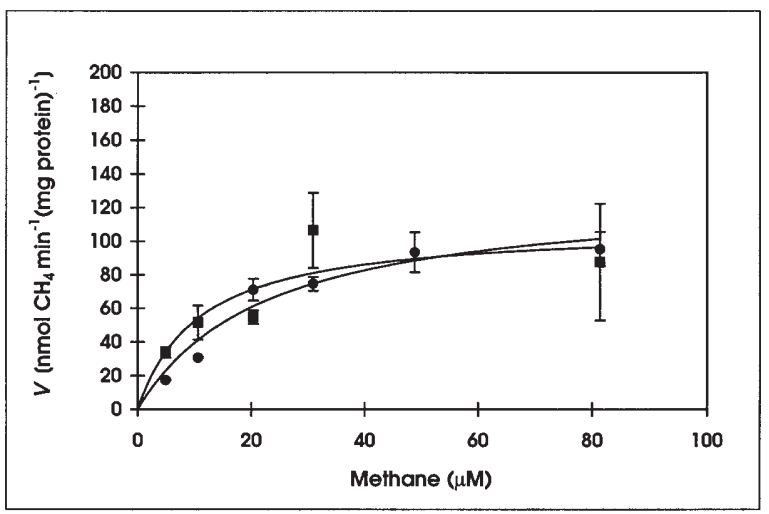

B

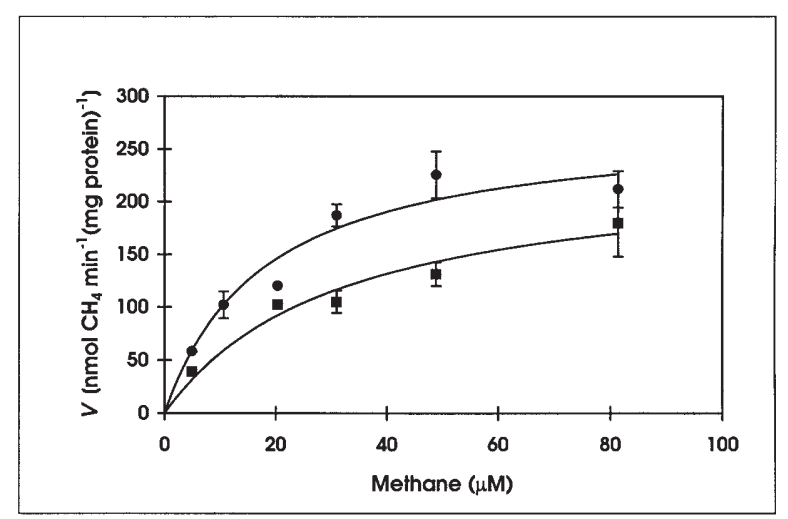

Fig. 1 A Methane consumption by Methylosinus trichosporium OB3b expressing particulate methane monooxygenase (pMMO) in the presence of varying dichloromethane concentrations without formate. B Methane consumption by $M$. trichosporium $\mathrm{OB} 3 \mathrm{~b}$ expressing pMMO in the presence of varying dichloromethane concentrations and $20 \mathrm{mM}$ formate $(\mathbf{O}=0 \mu \mathrm{M}$ dichloromethane, $\boldsymbol{\square}=$ $24 \mu \mathrm{M}$ dichloromethane). Symbols represent the mean of duplicate samples, and error bars indicate the spread of the measured values. Lines indicate the predicted rate of methane consumption using nonlinear regression to fit the Michaelis-Menten equation to the collected data

ane oxidation did not change significantly at a $95 \%$ confidence interval, but the apparent $K_{\mathrm{s}}$ did change as the dichloromethane concentration increased from 0 to $24 \mu \mathrm{M}$.

Table 1 Measured Michaelis-Menten kinetic parameters for methane oxidation by Methylosinus trichosporium OB3b expressing the particulate methane monooxygenase (pMMO) in the presence of varying trichloroethylene, dichloromethane, and formate concentrations. $M$. trichosporium OB3b was grown in the presence of $20 \mu \mathrm{M}$ copper. The kinetic parameters of the maximal degrada-
These results indicate that dichloromethane acts as a competitive inhibitor of methane oxidation.

In the absence of formate, as shown in Fig. $2 \mathrm{~A}$ and Table 1, trichloroethylene had little effect on the kinetics of methane oxidation. In the presence of formate, however, the effect of trichloroethylene on methane oxidation was substantially different. As shown in Fig. 2B, as the trichloroethylene concentration increased up to $61 \mu \mathrm{M}$, the apparent $V_{\max }$ of methane oxidation substantially decreased from $276 \pm 26$ to $109 \pm 17 \mathrm{nmol} \mathrm{min}^{-1}$ (mg protein $)^{-1}$ (significant at a $95 \%$ confidence interval). The change in apparent $K_{\mathrm{s}}$ for methane, however, was not significantly different at any of the tested concentrations of trichloroethylene, suggesting that trichloroethylene acts as a noncompetitive inhibitor of methane oxidation. The affinities of trichloroethylene for free enzyme $\left(K_{\mathrm{iE}}\right)$ and for enzyme already bound with substrate $\left(K_{\mathrm{iES}}\right)$ were calculated to be $28 \pm 3$ and $47 \pm 6 \mu \mathrm{M}$, respectively.

It should be stressed that trichloroethylene and dichloromethane inhibition of methane oxidation was observed only in the presence of formate. These results suggest the reduction of $\mathrm{pMMO}$ is the rate-limiting step in the oxidation of chlorinated hydrocarbons by whole cells expressing pMMO. Apparently formate acts as a nonessential activator since it may be oxidized by the formate dehydrogenase with the concomitant production of in vivo reductant. This conclusion is supported by the finding that with the exception of $61 \mu \mathrm{M}$ trichloroethylene, the apparent $V_{\max }$ of methane oxidation in the presence of formate and inhibitor was greater than the apparent $V_{\max }$ of methane oxidation found under similar conditions in the absence of formate (see Table 1). This finding indicates that reduction of pMMO by the in vivo reductant may also be the rate-limiting step in methane oxidation.

Trichloroethylene and dichloromethane consumption during inhibition experiments

Trichloroethylene and dichloromethane consumption was also monitored during the inhibition experiments to deter-

tion rate, $V_{\max }$, and the substrate concentration at the half-maximal degradation rate in whole cells, $K_{\mathrm{s}}$, were determined by using nonlinear regression to fit the Michaelis-Menten equation to the collected methane consumption data. Numbers in parentheses are the standard deviation of the measured values ( $N D$ not determined)

\begin{tabular}{|c|c|c|c|c|}
\hline \multirow[t]{2}{*}{ Inhibitor } & \multicolumn{2}{|l|}{ Without formate } & \multicolumn{2}{|c|}{ With $20 \mathrm{mM}$ formate } \\
\hline & 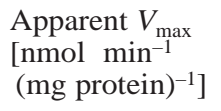 & Apparent $K_{\mathrm{s}}(\mu \mathrm{M})$ & 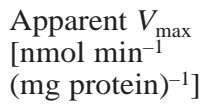 & Apparent $K_{\mathrm{s}}(\mu \mathrm{M})$ \\
\hline None & $130(15)$ & (7) & $276(26)$ & $(5.0)$ \\
\hline Dichloromethane $-24 \mu \mathrm{M}$ & $110(25)$ & 11 & $235(43)$ & $32(14)$ \\
\hline Trichloroethylene $-10 \mu \mathrm{M}$ & ND & ND & 214 (17) & $15 \quad(3.5)$ \\
\hline $22 \mu \mathrm{M}$ & $84 \quad(7.3)$ & $9.7 \quad(3.0)$ & $162(17)$ & $(4.7)$ \\
\hline $61 \mu \mathrm{M}$ & $121(23)$ & $25 \quad(12)$ & 109 (17) & $(8.4)$ \\
\hline
\end{tabular}


A

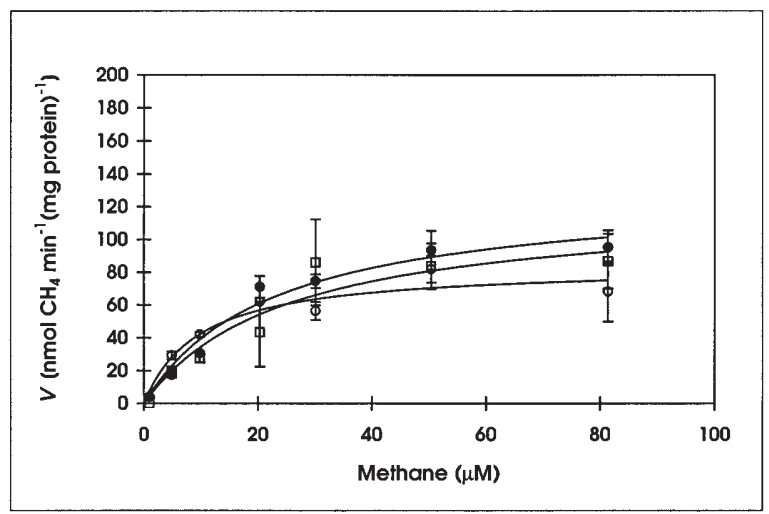

B

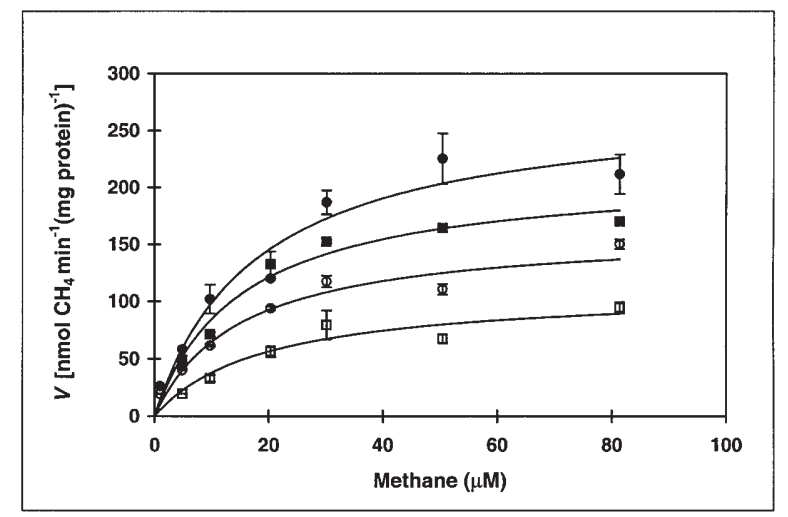

Fig. 2 A Methane consumption by Methylosinus trichosporium OB3b expressing particulate methane monooxygenase (pMMO) in the presence of varying trichloroethylene concentrations without formate. B Methane consumption by $M$. trichosporium OB3b expressing pMMO in the presence of varying trichloroethylene concentrations and $20 \mathrm{mM}$ formate $(\boldsymbol{O}=0 \mu \mathrm{M}$ trichloroethylene, $\mathbf{\square}=$ $10 \mu \mathrm{M}$ trichloroethylene, $\bigcirc=22 \mu \mathrm{M}$ trichloroethylene, and $\square=$ $61 \mu \mathrm{M}$ trichloroethylene). Symbols represent the mean of duplicate samples, and error bars indicate the spread of the measured values. Lines indicate the predicted rate of methane consumption using nonlinear regression to fit the Michaelis-Menten equation to the collected data

mine how much of these compounds was consumed during the assays. At an initial concentration of $22 \mu \mathrm{M}$ trichloroethylene, the rate of trichloroethylene degradation varied from $0.11 \mathrm{nmol} \mathrm{min}-1$ (mg protein $)^{-1}$ in the absence of formate to $0.25 \mathrm{nmol} \mathrm{min}-1$ (mg protein $)^{-1}$ in the presence of formate. At an initial concentration of $61 \mu \mathrm{M}$ trichloroethylene, however, the addition of formate had less effect on the rate of trichloroethylene degradation $\left[0.60 \mathrm{nmol} \mathrm{min}{ }^{-1}(\mathrm{mg} \text { protein })^{-1}\right.$ in the absence of formate

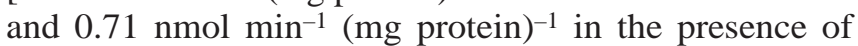
$20 \mathrm{mM}$ formate]. Dichloromethane degradation rates were higher, possibly due to the fact that it is structurally more similar to the primary substrate, methane. The rates of dichloromethane degradation, however, were much less than the rates of methane consumption. In the absence of formate, the average rate of dichloromethane degradation was found to be $2.3 \mathrm{nmol} \mathrm{min}{ }^{-1}(\mathrm{mg} \text { protein })^{-1}$. If $20 \mathrm{mM}$ formate was also provided, the rate of dichloromethane degradation increased to $6.1 \mathrm{nmol} \mathrm{min}^{-1}$ (mg protein $)^{-1}$.
Table 2 Measured rates of oxygen uptake by Methylosinus trichosporium OB3b grown with $20 \mu \mathrm{M}$ copper. Cells were incubated with acetylene for $30 \mathrm{~min}$. Acetylene was then removed by flushing prior to measurement of oxygen uptake. Formate was added as sodium formate. Numbers in parentheses are the standard deviation of the measured values

\begin{tabular}{|c|c|c|c|}
\hline Substrate & $\begin{array}{l}\text { Acetylene } \\
(\mu \mathrm{M})\end{array}$ & $\begin{array}{l}\text { Formate } \\
(\mathrm{mM})\end{array}$ & $\begin{array}{l}\text { Oxygen uptake rate } \\
{\left[\mathrm{nmol} \mathrm{min}^{-1}\right.} \\
\left.(\mathrm{mg} \text { protein })^{-1}\right]\end{array}$ \\
\hline None & $\begin{array}{r}0 \\
104\end{array}$ & $\begin{array}{l}0 \\
0\end{array}$ & $\begin{array}{ll}38 & (18) \\
30 & (14)\end{array}$ \\
\hline $\begin{array}{l}\text { Methane } \\
\qquad(2.5 \mathrm{mM})\end{array}$ & $\begin{array}{r}0 \\
104\end{array}$ & $\begin{array}{r}0 \\
20 \\
0 \\
20\end{array}$ & $\begin{aligned} 360 & (93) \\
630 & (50) \\
42 & (4.2) \\
93 & (23)\end{aligned}$ \\
\hline $\begin{array}{l}\text { Trichloroethylene } \\
\qquad(61 \mu \mathrm{M})\end{array}$ & $\begin{array}{r}0 \\
104\end{array}$ & $\begin{array}{r}0 \\
20 \\
0 \\
20\end{array}$ & $\begin{aligned} 86 & (5.0) \\
230 & (15) \\
31 & (14) \\
95 & (13)\end{aligned}$ \\
\hline
\end{tabular}

Acetylene and oxygen uptake experiments

In a separate set of experiments, acetylene was added to cells to inactivate pMMO as described in Materials and methods. Methane, dichloromethane, and trichloroethylene consumption was completely inhibited after $M$. trichosporium OB3b was incubated for $30 \mathrm{~min}$ with as little as $104 \mu \mathrm{M}$ acetylene (aqueous concentration). Since pMMO was the only form of MMO synthesized by $M$. trichosporium $\mathrm{OB} 3 \mathrm{~b}$ under these growth conditions, these experiments confirm that pMMO was the enzyme binding and transforming these substrates.

Oxygen uptake experiments were also performed to determine if trichloroethylene influenced other metabolic processes, including formate dehydrogenase activity or endogenous respiration that could lead to the observed noncompetitive inhibition of methane oxidation. For these experiments, the rates of oxygen uptake in the presence of methane, trichloroethylene, and formate both for acetylene-treated and untreated cells were measured and are compiled in Table 2.

Oxygen uptake due to endogenous respiration in the absence of any substrate was $38 \mathrm{nmol} \mathrm{min}{ }^{-1}$ (mg protein $)^{-1}$ for untreated cells. The rate of oxygen consumption increased by an order of magnitude with the addition of methane to untreated cells, and increased approximately twofold more when formate was also added. When $61 \mu \mathrm{M}$ trichloroethylene was added to untreated cells, oxygen uptake was seen at a rate of $86 \mathrm{nmol} \mathrm{min}{ }^{-1}$ (mg protein) ${ }^{-1}$, greater than the rate of oxygen uptake in the absence of any substrate. Furthermore, with the addition of formate together with trichloroethylene, oxygen consumption increased approximately threefold. These results support the findings that addition of formate enhances not only wholecell trichloroethylene oxidation, but also whole-cell methane oxidation for cells expressing pMMO.

If the cells were first treated with acetylene to inactivate $\mathrm{pMMO}$, however, the rate of oxygen consumption 
due to methane oxidation was not statistically different from that of endogenous respiration in the absence of any substrate. If formate was added together with methane to acetylene-treated cells, the rate of oxygen consumption increased significantly at a $95 \%$ confidence interval from 38 to $93 \mathrm{nmol} \mathrm{min}^{-1}$ (mg protein) ${ }^{-1}$, indicating that formate oxidation created reducing equivalents that were utilized for respiration. If trichloroethylene was added to acetylene-treated cells, the rate of oxygen uptake was again indistinguishable from that for endogenous respiration. If formate was added together with trichloroethylene, the rate of oxygen uptake increased in acetylene-treated cells to $95 \mathrm{nmol} \mathrm{min}^{-1}$ (mg protein) $)^{-1}$, similar to that seen for simultaneous oxidation of methane and formate by acetylene-treated cells. These results indicate that neither the oxidation of formate nor endogenous respiration was affected by the presence of trichloroethylene.

\section{Discussion}

Several earlier studies have examined cometabolism of halogenated hydrocarbons by M. trichosporium OB3b expressing sMMO in the presence of methane. Typically the mechanism of inhibition in whole cells has been observed to be competitive in nature (Speitel et al. 1993; Van Hylckama Vlieg et al. 1996), as has been using sMMO purified from M. trichosporium OB3b (Fox et al. 1990). With the exception of a common primary substrate, however, pMMO and sMMO show no similarity on a molecular level and have very different substrate ranges (Burrows et al. 1984; Semrau et al. 1995a).)

The results presented here show that the mechanism of cooxidation may also differ since dichloromethane appears to be a competitive inhibitor, while trichloroethylene acted as a noncompetitive inhibitor of methane oxidation by $M$. trichosporium OB3b expressing pMMO. The possibility that these changes were due to the chlorinated hydrocarbon or to its oxidative products' inactivation of pMMO was avoided through the experimental design. Previous research has shown that both trichloroethylene and dichloromethane oxidation by methanotrophs expressing pMMO followed hyperbolic kinetics up to 61 $\mu \mathrm{M}$ trichloroethylene (Lontoh and Semrau 1998) and 80 $\mu \mathrm{M}$ dichloromethane (J. D. Semrau, unpublished work), confirming a lack of substrate toxicity. Also, the degradation of methane in the presence of trichloroethylene was linear when sampled multiple times over $2 \mathrm{~h}$ and over $1 \mathrm{~h}$ in the presence of dichloromethane, verifying that pMMO activity did not decrease in these assays (data not shown).

To gain insights into the mechanism by which dichloromethane and trichloroethylene inhibit whole-cell methane oxidation by $M$. trichosporium OB3b expressing pMMO, it is more valid to make comparisons to another copper-containing oxygenase, ammonia monooxygenase (AMO). Both AMO and pMMO are believed to have copper and possibly iron in the active site (Ensign et al. 1993; Nguyen et al. 1996; Zahn and DiSpirito 1996; Zahn et al.
1996; Takeguchi et al. 1998), and the activity of both enzymes in membrane preparations can be enhanced with the addition of copper (Ensign et al. 1993; Semrau et al. 1995b; Zahn and DiSpirito 1996). AMO and pMMO also have similar predicted amino acid sequences and hydropathic profiles (McTavish et al. 1993a; Semrau et al. 1995a). Finally, both enzymes are irreversibly inhibited by acetylene (Prior and Dalton 1985; Hyman et al. 1992), and the whole-cell kinetics of ammonia oxidation in the presence of several inhibitors followed multiple inhibition patterns (Keener and Arp 1993). In this report, methane and ethylene acted as competitive inhibitors of whole-cell ammonia oxidation, while several compounds including ethane, propane, chloromethane, bromomethane, iodomethane, chloroethane, bromoethane, and iodoethane acted as noncompetitive inhibitors. From these results, it was concluded that the AMO consists of at least two substrate-binding sites and that oxidation can occur at either site.

Recent studies on purified pMMO preparations show the existence of multiple copper centers in pMMO (Nguyen et al. 1996, 1998; Zahn and DiSpirito 1996). If these centers are the locations of substrate binding, they could be responsible for the finding of differential inhibition of methane oxidation by dichloromethane and trichloroethylene. As suggested by Nguyen et al. (1996), these copper centers may not be identical, and if the active site structures are slightly different, a hypothesis can be constructed to explain the observed inhibition patterns. Methane and dichloromethane may bind equally well to both sites; thus, dichloromethane acts as a competitive inhibitor of methane oxidation. Possibly due to steric properties, trichloroethylene may be less effectively bound to one site, thus acting as a noncompetitive inhibitor. Consideration of the equilibrium dissociation constants $K_{\mathrm{iE}}$ and $K_{\mathrm{iES}}$ for trichloroethylene, however, suggests that trichloroethylene competes to some extent with methane for binding sites $\left(K_{\mathrm{iE}}<\right.$ $\left.K_{\mathrm{iES}}\right)$. Similar results have been seen for several of the noncompetitive inhibitors of ammonia oxidation (Keener and Arp 1993).

It has also been recently discovered that both AMO and pMMO have multiple gene copies (McTavish et al. 1993b; Semrau et al. 1995a). Furthermore, insertional mutagenesis of the AMO gene clusters has revealed that they are differentially expressed and have different activities (Hommes et al. 1998). This finding is interesting since a mixture of multiple forms of the same enzyme can appear to be noncompetitively inhibited if one form of the enzyme is actually competitively inhibited (Segel 1993). The whole-cell data collected here does not allow for distinguishing between these possibilities; these studies should be performed using purified pMMO preparations. Unfortunately, the highest activity preparations of purified pMMO still only account for a fraction of the whole-cell activity (Zahn and DiSpirito 1996; Nguyen et al. 1998). Such activity loss is partially due to pMMO lability upon removal from the membranes, which makes it difficult to perform these experiments at this time.

Although the mechanism by which trichloroethylene and dichloromethane inhibit methane oxidation by pMMO 
cannot be specifically determined using whole-cell analysis, it is apparent that substrate oxidation by cells expressing pMMO is strongly affected by the availability of both copper and formate. It has been previously shown that methanotrophs expressing pMMO can not degrade trichloroethylene if grown with $2.5-3 \mu \mathrm{M}$ copper, but can do so if the copper concentration is increased to $20 \mu \mathrm{M}$ or more (Smith et al. 1997; Lontoh and Semrau 1998). It is possible that providing more copper fills active sites within $\mathrm{pMMO}$ that are deficient in copper. Alternatively, higher copper concentrations may cause differential expression of the multiple pmo operons that then enables cells to degrade trichloroethylene. The effect of copper on substrate oxidation is further complicated by the addition of formate. Since copper may help maintain optimal redox conditions in pMMO (Nguyen et al. 1996; Zahn and DiSpirito 1996), the addition of formate and extra copper may enhance pMMO activity. Formate, through the provision of excess reducing equivalents, apparently acts as a nonessential activator of whole-cell methane oxidation. Formate, however, also accentuates the inhibitory effect of both dichloromethane and trichloroethylene on methane oxidation, and enhances the rates of dichloromethane and trichloroethylene degradation. It has been observed previously that addition of formate increases the affinity of $M$. trichosporium OB3b for trichloroethylene (Lontoh and Semrau 1998). Formate may enhance the binding of chlorinated hydrocarbons to pMMO by keeping the enzyme in a reduced, active form, thus enhancing their inhibition of methane oxidation.

Finally, it should be noted that these studies were performed using whole cells. As such, it is difficult to extend the findings to pMMO exclusively. The results may show the effect of dichloromethane and trichloroethylene on other enzymes in close association with pMMO, although trichloroethylene had no effect on formate dehydrogenase activity as measured by oxygen uptake. Furthermore, the collected kinetic constants should be considered as apparent constants since they were not collected using purified enzyme preparations. The results, however, are still important because whole cells will be used in most treatment systems and most known methanotrophs can only express pMMO. For these reasons, it is important to learn more about how cells synthesizing pMMO degrade mixtures of substrates for effective site remediation. For example, field experiments at Moffett Naval Air Station showed that in situ methanotrophic populations once stimulated with the provision of methane and oxygen could degrade mixtures of chlorinated ethenes (Semprini et al. 1990). Although the form of MMO synthesized was not explicitly measured, later analysis of the kinetics of trichloroethylene degradation suggested that pMMO was active in situ (McCarty 1997). Since sMMO and pMMO have very different kinetics and substrate ranges, and also appear to be differentially inhibited by pollutants such as trichloroethylene, the rates of both methane and pollutant oxidation may not be accurately predicted by simple competitive inhibition, particularly when first-order kinetics cannot be assumed (i.e., $K_{\mathrm{s}}>\mathrm{S}$ ). Such deviations can cause erroneous predic- tions of the stimulation of methanotrophic activity and of the amount of time necessary for adequate clean-up.

Acknowledgements Research support from the National Science Foundation to J. D. Semrau (grant no. MCB-9708557) is gratefully acknowledged.

\section{References}

Alvarez-Cohen L, McCarty PL (1991) Effects of toxicity, aeration, and reductant supply on trichloroethylene transformation by a mixed methanotrophic culture. Appl Environ Microbiol 57:228235

Brusseau GA, Tsien HC, Hanson RS, Wackett LP (1990) Optimization of trichloroethylene oxidation by methanotrophs and the use of a colorimetric assay to detect soluble methane monooxygenase activity. Biodegradation 1:19-29

Burrows KJ, Cornish A, Scott D, Higgins IJ (1984) Substrate specificities of the soluble and particulate methane monooxygenases of Methylosinus trichosporium OB3b. J Gen Microbiol 5:335342

Cardy DLN, Laidler V, Salmond GPC, Murrell JC (1991) Molecular analysis of the methane monooxygenase (MMO) gene cluster of Methylosinus trichosporium OB3b. Mol Microbiol 5:335-342

Cornish-Bowden A (1979) Fundamentals of enzyme kinetics. Butterworths, London, pp 73-98

DiSpirito AA, Gulledge J, Shiemke AK, Murrell JC, Lidstrom ME, Krema CL (1992). Trichloroethylene oxidation by the membrane-associated methane monooxygenase in type I, II, and type X methanotrophs. Biodegradation 2:151-164

Ensign SA, Hyman MR, Arp DJ (1993) In vitro activation of ammonia monooxygenase from Nitrosomonas europaea by copper. J Bacteriol 175:1971-1980

Fox BG, Borneman JG, Wackett LP, Lipscomb JD (1990) Haloalkene oxidation by the soluble methane monooxygenase from Methylosinus trichosporium OB3b: mechanistic and environmental implications. Biochemistry 29:6419-6427

Hanson RS, Hanson TE (1996) Methanotrophic bacteria. Microbiol Rev 60:439-471

Hommes NG, Sayavedra-Soto LA, Arp DJ (1998) Mutagenesis and expression of amo, which encodes for ammonia monooxygenase in Nitrosomonas europaea. J Bacteriol 180:3353-3359

Howard PH, Meylan WH (1997) Handbook of physical properties of organic chemicals. CRC Lewis, Boca Raton

Hyman MR, Arp DJ (1992) ${ }^{14} \mathrm{C}_{2} \mathrm{H}_{2}$ - and ${ }^{14} \mathrm{CO}_{2}$-labeling studies of the de novo synthesis of polypeptides by Nitrosomonas europaea during recovery from acetylene and light inactivation of ammonia monooxygenase. J Biol Chem 267:1534-1545

Keener WK, Arp DJ (1993) Kinetic studies of ammonia monooxygenase inhibition in Nitrosomonas europaea by hydrocarbons and halogenated hydrocarbons in an optimized whole-cell assay. Appl Environ Microbiol 59:2501-2510

Lontoh S, Semrau JD (1998) Methane and trichloroethylene degradation by Methylosinus trichosporium OB3b expressing the particulate methane monooxygenase. Appl Environ Microbiol 64:1106-1114

McCarty PL (1997) Aerobic cometabolism of chlorinated aliphatic hydrocarbons. In: Ward CH, Cherry JA, Scalf MR (eds) Subsurface restoration. Ann Arbor Press, Chelsea, Mich, pp 373-395

McTavish H, Fuchs JA, Hooper AB (1993a) Sequence of the gene coding for ammonia monooxygenase in Nitrosomonas europaea. J Bacteriol 175:2436-2444

McTavish H, et al (1993b) Multiple copies of genes coding for electron transport proteins in the bacterium Nitrosomonas europaea. J Bacteriol 175:2445-2447

Morel FM, Hering JG (1991) Principles and applications of aquatic chemistry. Wiley, New York 
Nguyen HHT, et al (1996) X-ray absorption and epr studies on the copper ions associated with the particulate methane monooxygenase from Methylococcus capsulatus (Bath): $\mathrm{Cu}(\mathrm{I})$ ions and their implications. J Am Chem Soc 118:12766-12776

Nguyen HHT, Elliott SJ, Yip JHK, Chan SI (1998) The particulate methane monooxygenase from Methylococcus capsulatus (Bath) is a novel copper-containing three-subunit enzyme. J Biol Chem 273:7957-7966

Oldenhuis R, Vink RLJM, Janssen DB, Witholt B (1989) Degradation of chlorinated aliphatic hydrocarbons by Methylosinus trichosporium OB3b expressing soluble methane monooxygenase. Appl Environ Microbiol 55:2819-2826

Prior SD, Dalton H (1985) Acetylene as a suicide substrate and active site probe for methane monooxygenase from Methylococcus capsulatus (Bath). FEMS Microbiol Lett 29:105-109

Rosenzweig AC, Frederick CA, Lippard SJ, Nordlund P (1993) Crystal structure of a bacterial non-haem iron hydroxylase that catalyses the biological oxidation of methane. Nature 366:537-43

Segel IH (1993) Enzyme kinetics. Wiley, New York, pp 196-198

Semprini L, Roberts PV, Hopkins GD, McCarty PL (1990) A field evaluation of in-situ biodegradation of chlorinated ethenes. 2. Results of biostimulation and biotransformation experiments. Groundwater 28:715-727

Semrau JD, et al (1995a) Particulate methane monooxygenase genes in methanotrophs. J Bacteriol 177:3071-3079

Semrau JD, Zolandz D, Lidstrom ME, Chan SI (1995b) The role of copper in the pMMO of Methylococcus capsulatus Bath: a structural vs. catalytic function. J Inorg Biochem 58:235-244
Smith KS, Costello AM, Lidstrom ME (1997) Methane and trichloroethylene oxidation by an estuarine methanotroph, Methylobacter sp. strain BB5.1. Appl Environ Microbiol 63:4617-4620

Speitel GE, Thompson RC, Weissman D (1993) Biodegradation kinetics of Methylosinus trichosporium OB3b at low concentrations of chloroform in the presence and absence of enzyme competition by methane. Water Res 27:15-24

Stirling DI, Dalton H (1977) Effect of metal-binding agents and other compounds on methane oxidation by two strains of Methylococcus capsulatus. Arch Microbiol 114:71-76

Takeguchi M, Miyakawa K, Okura I (1998) Purification and properties of particulate methane monooxygenase from Methylosinus trichosporium OB3b. J Mol Catal A Chem 132:145-153

Van Hylckama Vlieg JET, DeKoning W, Janssen DB (1996) Transformation kinetics of chlorinated ethenes by Methylosinus trichosporium OB3b and detection of unstable epoxides by on-line gas chromatography. Appl Environ Microbiol 62:3304-3312

Westrick JJ, Mello JW, Thomas RF (1984) The groundwater supply survey. J Am Water Works Assoc 76:52-59

Zahn JA, DiSpirito AA (1996) Membrane-associated methane monooxygenase from Methylococcus capsulatus (Bath). J Bacteriol 178:1018-1029

Zahn JA, Arciero DM, Hooper AA, DiSpirito AA (1996) Evidence for an iron center in the ammonia monooxygenase from Nitrosomonas europaea. FEBS Lett 397:35-38 